Anne Ellerup Nielsen*

\title{
Den argumentative teksttype i reklamer
}

\begin{abstract}
The text-typology model developed by Jean-Michel Adam is one of the most welldefined and operational models if one wants to categorize whole texts or text fragments into smaller units. Given that a texttype is the result of specific functional and structural relations between micro- and macropropositions, it is a multicriterial model which takes into account both the syntactic, semantic and pragmatic features of texts. However, the model seems to offer some problems in establishing the limits between the argumentative and the descriptive text type. This imprecision is apparently due to the lack of distinction between the discourse potential of evaluative and referential propositions. This problem will be demonstrated on examples from the genre of advertising material which, because of its persuasive purpose, is particularly rich in argumentative features.
\end{abstract}

Tekstlingvistikken, diskursanalysen og genreanalysens gennembrud i løbet af de sidste 20-25 år har forøget interessen for makro- og mikrostrukturelle afgrænsninger af tekster og herunder teksttyper. De forskellige teoretiske og metodiske indfaldsvinkler der er blevet anvendt $\mathrm{i}$ forbindelse med tekstlingvistiske studier, har betydet, at begrebet teksttyper er blevet defineret på basis af talrige kriterier, hvoraf både genre, kommunikativt formål, sproghandling og syntaks har udgjort det bærende fundament. Jeg vil ikke her komme ind på alle de tekstlingvistiske traditioner der har tilnærmet sig en defintion af begrebet teksttype, men henvise til Morten Pilegård og Finn Frandsens artikel: Texttype (1997) for en oversigt over kriterier, som har betydning for distinktionen mellem forskellige tekstdimensioner, herunder sprogtype, teksttype, diskurstype og genre.

Med udgangspunkt i den franske tekstlingvist Jean-Michel Adams definition af teksttypesekvenser vil jeg i det følgende se nærmere på

* Anne Ellerup Nielsen

Handelsh $\phi j$ skolen i Aarhus

Fransk Institut

Fuglesangs Allé 4

DK-8210 Aarhus V

Hermes, Journal of Linguistics no. 20 - 1998 
forholdet mellem brugen af en bestemt teksttype: den argumentative teksttype og en bestemt tekstgenre: reklamen. Adam har fra midten af firserne publiceret en lang række værker om teksttypologi, hvoraf blandt de vigtigste kan nævnes: Le texte narratif (1985), Quels types de textes? (1985a), Types de séquences textuelles élémentaires (1987), i samabejde med A. Petitjean Le texte décriptif (1989), Eléments de linguistique textuelle (1990), samt Les textes: types et prototypes (1992), som fremstillingen her er baseret på. Jeg anser Adams teksttypologiseringsmodel for en af de mest operationelle modeller på markedet, fordi den er multikriteriel i den forstand, at den tager højde for både en strukturel og en funktionel dimension som basis for bestemmelsen af en tekst. Grunden til at jeg har valgt at anskue den argumentative teksttype i lyset af reklamegenren er, at argumentation på forhånd synes indskrevet i denne genre $\mathrm{i}$ form af en særlig persvasionsstrategi, som er forbundet med reklamens funktionelle virke ${ }^{1}$.

Jeg anser dog ikke Adams sekventielle teksttypemodel for at være helt uproblematisk. Et af problemerne hænger sammen med definitionen og afgrænsningen af sekvenser på det mikropropositionelle niveau, hvilket f.eks. vanskeliggør typologiseringen af reklamedeltekster som f.eks. slogans. Dette problem mener jeg ikke, at Adam tager særlig godt højde for. Derfor vil jeg nedenfor specielt beskæftige mig med den argumentative teksttype, sådan som den kommer til udtryk i reklamer med henblik på at nå til en klarere indkredsning af de elementer, der ligger til grund for definitionen af specielt denne teksttype. Efter en introduktion til Adams typologiseringsmodel, vil jeg eksemplificere to konkrete problemstillinger, som knytter sig til modellen, nemlig makropropositionernes syntagmatiske opbygning, samt den deskriptive propositions paradigmatiske struktur.

\section{Tekstens organisationsplaner}

Adam definerer en tekst som en konfiguration, der er styret af forskellige moduler eller undersystemer i konstant interaktion med hinanden (Adam 1992: 21). Disse moduler eller undersystemer inddeler

\footnotetext{
1 Jeg henviser til min Ph.d.-afhandling: Argumentationsstrategier i franske prosentationsbrochurer - Fra det sproglige til det retoriske niveau (1996), samt til "Persuasion disguised as description - An Example of Argumentation in the Company Brochure", Ellerup Nielsen/Nølke (1991) for en mere detaljeret analyse af argumentationsstrategier $\mathrm{i}$ forbindelse med brochuremateriale.
} 
han i to grupper, hvoraf den første gruppe omfatter det pragmatiskfunktionelle plan (configuration pragmatique) og den næste gruppe omfatter tekstens sproglige komponenter i form af en række propositioner (suite de propostions). Under det pragmatisk-funktionelle plan henregner Adam tekstens illokutionære hensigt (visée illocutoire), dens udsigelsesspor (répérages énonciatifs), samt dens referentielle repræsentation, som kommer til udtryk i form af dens semantiske kohæsion (cohésion sémantique). Tekstens linearitet sikres gennem på den ene side en sætnings- og tekstgrammatisk komponent, som binder tekstenhederne sammen, og en sekventiel opbygning i enheder, som udgøres af prototypiske teksttypesekvenser. Overordnet disse tekstinterne planer befinder sig en tekstekstern dimension med selve kommunikationen (discours), afsender/modtager (interaction sociale), og teksgenre (genres et sous-genres de discours) (op.cit.: 17) i fokus.

Den dimension som har Adams største opmærksomhed, er ikke den pragmatiske dimension, men hvad han selv kalder tekstens tekstur (texture) og dens komponentielle struktur (structure componentielle) (Adam 1996: 33), altså de komponenter som sikrer tekstens sammenhæng og linearitet. Det forklarer også hans særlige interesse for teksttyperne. Teksttyperne deler han op i fem prototyper: den narrative, den deskriptive, den argumentative, den eksplikative og den dialogale prototype. De giver teksten en bestemt sekventiel struktur, som sammen med tekstens retoriske struktur danner dens komponentielle struktur. Den retoriske struktur definerer han som tekstplaner, der er mere eller mindre styret af den genre, teksten tilhører (ibid.). Forholdet mellem den retoriske og den sekventielle struktur kan være mere eller mindre fast i den forstand, at der, ifølge Adam, ikke altid er et én-til-én forhold mellem brugen af en bestemt teksttype og en bestemt genre. Der vil dog altid være tale om, at visse teksters struktur er mere repræsentativ for en given tekstgenre end andres parallelt med, at bestemte sproglige former vil være mere repræsentative for en bestemt teksttype end andre sproglige former, hvilket netop forklarer Adams betegnelse af teksttyperne som prototyper (Adam 1992: 7, 30).

\section{Den sekventielle struktur}

Går vi ned på tekstens sekventielle niveau, opererer Adam med to konfigurationer af sekvensstrukturer. Den første af disse består af en række analoge eller alternerende sekvenser og den anden af en række indlej- 
rede sekvenser. Tekster kan være homogent opbygget i form af ensartede teksttyper, men langt de fleste tekster er heterogene. Heterogene tekster er enten opbygget således, at en bestemt teksttype er indlejret i en anden teksttype, som f.eks. en dialog indeholdende en narrativ sekvens: [dialogal sekvens [narrativ sekvens] dialogal sekvens]. Heterogene tekster kan dog også bestå af komplekse teksttyper, som indeholder spor fra to eller flere teksttyper samtidigt. I denne struktur er det vanskeligt at skelne teksttyperne klart fra hinanden. De indgår i et dominansforhold, således at en teksttype er styrende for en anden teksttype, som f.eks. hvis en tekst består af en række løsrevne deskriptive propositioner med enkelte argumentative spor: [argumentativ sekvens > deskriptiv sekvens]. Men hvilken teksttype, der i så fald er den dominerende og på hvilke kriterier den kan udledes, er ikke klart markeret hos Adam. Dette problem vil jeg forsøge at indkredse nedenfor, men lad os forinden se nærmere på, hvordan Adam definerer den enkelte teksttypesekvens.

\section{Teksttypesekvensen}

En teksttypesekvens defineres af Adam som en relationel autonom tekstenhed, der interagerer med den tekstenhed, den selv indgår i. Den består af makropropositioner, der igen består af propositioner, hvor imellem der kan etableres en bestemt semantisk relation. Dens opbygning som et kinesisk æskesystem gør, at teksekvensens omfang kan varierere fra en eller to ytringer til hele tekster eller tekstdele (Adam 1992: 28-30).

Når Adam kun opererer med fem prototypiske sekvenser og eksempelvis har nedlagt den ekspositoriske teksttype, som mange af hans forgængere opererer med, ${ }^{2}$ er det fordi han betragter visse varianter på et andet tekstplan end teksttypesekvensen. For Adam er eksposition og instruktion et udtryk for sproghandlinger, som artikuleres via den deskriptive teksttype (op.cit.: 33). Parallelt hermed kan den argumentative teksttype komme til udtryk ved hjælp af forskellige mikro-sproghandlinger: love, spørge, beordre, assertere, etc. såvel som ved hjælp af konnektorer: fordi, men, altså etc., eller blot i form af bestemte euforiske eller lovprisende beskrivelser (op.cit.: 23), hvilket vi skal se eksempler på senere. Sproghandlingen er med andre ord knyttet til tekstens in-

2 Cf. f.eks. E. Werlich (1979). 
tentionelle værdi, hvad enten det gælder en tekst i sin helhed eller en mindre tekstenhed. Vi kan altså foreløbigt konkludere, at Adam ser tekstens sproglige karakteristika og ikke den eller de tilgrundliggende sproghandlinger som afgørende for tekstsekvensens prototypiske struktur. Grænsen mellem disse to planer er dog ikke så let at trække, hvilket jeg senere skal vende tilbage til.

\section{Den argumentative teksttype}

Den argumentative teksttype består af en række makropropositioner, hvoraf to kan karakteriseres som kernepropositioner. Den argumentative struktur opstår ved, at der mellem to propositioner kan etableres en bestemt semantisk relation, hvor den ene proposition fungerer som argument og den anden som konklusion. Det er således ikke de enkelte propositioners egenskaber, men relationen mellem dem, der genererer den argumentative teksttype.

Relationen mellem argument og konklusion hviler på en bestemt forbindelsesregel, som i den klassisk-retoriske tradition betegnes som topos. Topos er udtryk for de konventionelle forbindelser, vi etablerer mellem ting eller handlinger. Det kan dreje sig om årsagsforbindelser af typen Peter ligger i sengen fordi han er syg!, eller om ræsonnementer: Vejen er våd. Det har regnet! Topos er således baseret på et generelt princip som taleren henviser til i en oftest implicit form. I de to eksempler ovenfor kan topos ekspliciteres som følger: Det er ret almindeligt at holde sengen, hvis man er syg, og når det regner, bliver vejen våd. Den klassiske syllogisme er et godt eksempel på, at topos er ekspliciteret i form af overpræmissen:

Appelsiner er sunde (overpræmis)

Lise spiser appelsiner (underpræmis)

Lise er sund (konklusion).

I enthymemet, som er en amputeret form for syllogisme, er overpræmissen udeladt:

Lise spiser appelsiner

Lise er sund

Den argumentative teksttype bygger altså på denne formelle ræsonneringsstruktur. Den nyere forskning inden for argumentationsteorien har dog udskiftet det formelt logiske argumentationsskema, som den klas- 
siske syllogisme er et eksempel på, med en model der tager højde for brugen af sproget i praktiske kommunikationssituationer. Adams argumentative teksttype bygger på denne model, som den amerikanske videnskabsteoretiker Stephen Toulmin opstillede midt i 50'erne i sit brud med den formelle logik (Toulmin, 1969). Grundtanken i Toulmins argumentationsmodel er, at forbindelsen mellem en påstand og et belæg altid er understøttet af en hjemmel, der igen kan understøttes af en rygdækning, som er i stand til at levere yderligere dokumentation for, at hjemmelen er relevant (op.cit.: 98). Taler påberåber sig således i princippet hjemmelen samt dens rygdækning i udsigelsesøjeblikket som garanti for forbindelsens rigtighed og relevans, uden at dette nødvendigvis klargøres eksplicit for modtageren. De tre grundkomponenter i Toulmins model: påstand, belæg og hjemmel ligger til grund for Adams argumentative teksttype, hvis prototypiske struktur ser ud som følger:

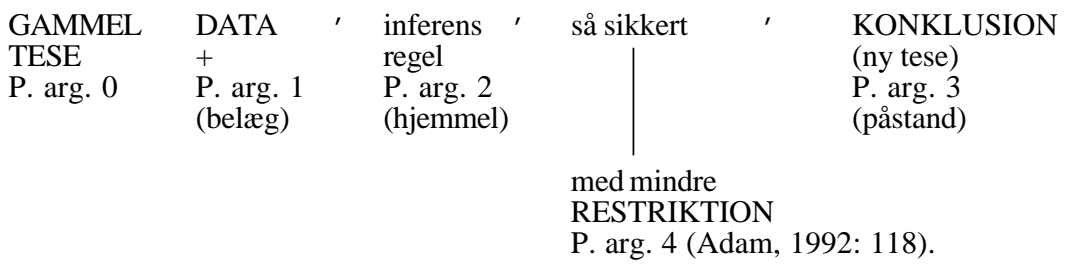

Den argumentative teksttypesekvens består altså basalt set af tre makropropositioner (P. arg. 1,2,3), som tager udgangspunkt i en eller anden forudgående tese (P. arg. 0), der udgør en generel tese eller påstand i en forudgående argumentativ sekvens. Hvad angår P. arg. 4 er det en makroproposition, der tager højde for, at påstanden i P. arg. 3 potentielt set kan tilbagevises, hvis den hjemmel, der kommer til udtryk i P. arg. 2, af den ene eller den anden grund ikke gælder i den pågældende udsigelsessituation. Rækkefølgen af de enkelte makropropositioner i skemaet følger den lineære struktur for argumentation, det vil sige den progressive struktur i analogi med den klassiske syllogisme ( $p$, altså q), men der er intet til hinder for, at argumentation kan manifestere sig i en regressiv og dermed ræsonnerende struktur, hvor et belæg følger efter en påstand ( $\mathrm{p}$, fordi $\mathrm{q})$. Hvor den progressive argumentationsstruktur ofte har til formål at konkludere et forhold, er den regressive argumentationsstruktur primært knyttet til legitimeringen af et forhold. 
Selvom den argumentative teksttype består af komponenter som tilsammen danner en fast prototypisk struktur, er Adam ikke blind for, at tekster der kategoriseres som argumentative, kan variere utroligt meget i form. Argumentative tekster er ifølge Adam ikke nødvendigvis knyttet til en specifik form på det globale tekstplan; men han fastholder ikke desto mindre, at man kan udpege en bestemt sekventiel form på det lokale tekstplan, der kan identificeres som en argumentativ kernestruktur (op.cit.: 117). Han problematiserer i den forbindelse selv den klassiske distinktion mellem argumentation og demonstration (at be- eller afkræfte en bestemt hypotese), ud fra den begrundelse, at der netop ikke findes et bestemt ideal for argumentative tekster som f.eks. den videnskabelige tekst. Den argumentative dynamik er under alle omstændigheder den samme, hvad enten det gælder argumentation eller demonstration. Spørgsmålet er da også, som vi skal se, om Adam har ret i, at man fuldstændigt kan isolere en teksts sekventielle form fra den funktion den opfylder.

\section{Argumentation og reklameretorik}

I 1997 udkom bogen L'argumentation publicitaire - Rhétorique de l'éloge et de la persuasion, som Adam har udgivet sammen med den franske lingvist Marc Bonhomme. Den pragmatiske dimension, som Adam har valgt at se mere eller mindre bort fra i sine første arbejder om teksttypologi, er i fokus i denne bog og undersøges nærmere ud fra en retorisk indfaldsvinkel.

Reklamen defineres som en bestemt genre, hvis funktion er dobbelttydig. Reklamer vil både oplyse forbrugeren om noget, han ikke ved $\mathrm{i}$ forvejen, og opfordre ham til at realisere en bestemt handling, det vil sige at reklamer er forbundet med to sproghandlinger: oplysning og anbefaling. Denne komplekse funktion afspejler sig ofte på det sproglige plan via en konstaterende sproghandling som henviser til produktet og dets egenskaber og en argumenterende (inciterende) sproghandling, som kommmer til udtryk i en som oftest implicit form: jeg råder dig til at købe dette produkt. Det er ifølge Adam og Bonhomme denne pragmatiske kompleksitet, der gør reklamen til en persvasivt informerende genre (Adam/Bonhomme 1997: 25).

Den informerende og den persvasive funktion tydeliggøres endvidere i forfatternes indplacering af reklamen i forhold til de tre klassiskretoriske genrer: juridiktion, deliberation og epidiktion. Reklamen ka- 
rakteriseres i denne forbindelse som en subtil blanding mellem de to sidstnævnte genrer. Ifølge Chaïm Perelman, som er en af den klassiske retoriks nytænkere, har epidiktionen - lovprisningen - primært til formål at styrke tilslutningen til bestemte værdier, der er fælles for en større gruppe mennesker. Derfor skal epidiktionen ofte tiltrække via moralske argumenter, som sætter taler i et gunstigt lys. I reklamer kommer den epidiktoriske genre til udtryk gennem beskrivelsen, hvorimod den deliberatoriske genre manifesterer sig via argumentation. Disse to sproglige funktioner: at producere en diskursiv repræsentation (beskrive) $\mathrm{og}$ at argumentere, er dog så tæt forbundne, at det persvasive i reklamer ofte er maskeret som beskrivelse. Beskrivelsen er næsten altid lovprisning, fordi nedgørelse af konkurrerende produkter er forbudt ved lov. Resultatet er en ofte euforisk og hyperbolsk beskrivelse af produktet, som i kraft af lovprisningen ikke kan adskilles for opfordringen til $\mathrm{k} \emptyset \mathrm{b}$, hvor det argumenterende element kommer ind (op.cit.: 92).

Hvad man tydeligt fornemmer i Bonhomme og Adams fremstilling er altså et vist forbehold, når det gælder distinktionen mellem beskrivelse og argumentation i reklamer. At grænserne mellem disse elementer er flydende er med andre ord et træk, der er indskrevet i reklamen som genre. Det er netop denne udviskning af grænser, der også får mig til at tage forbehold, når vi bevæger os på det tekstsekventielle niveau. Jeg vil derfor i det følgende se nærmere på, hvorvidt disse flydende grænser på det funktionelle niveau hænger sammen med visse uklarheder med hensyn til, hvilke semantiske enheder der gør sig gældende på det propositionelle niveau.

\section{Propositionernes karakteristika}

Som allerede nævnt består teksten af en eller flere sekvenser, som følger efter eller er indlejret i hinanden. Sekvenserne er bygget op af sproglige enheder, hvorimellem de semantiske relationer er bestemmende for, til hvilken prototype en sekvens kan henregnes. For den argumentative teksttypes vedkommende består den semantiske relation mellem enhederne i, at en proposition fungerer som legitimering for en anden proposition. Et af de spørgsmål der i den forbindelse trænger sig på, angår propositionens omfang.

I Adams sekvensanalyser falder en makroproposition sammen med en enkelt ytring, som typisk svarer til en helsætning, subsidiært en selvstændig ledsætning (som f.eks. en parentetisk relativ sætning) indehol- 
dende en proposition, der defineres på basis af en prædikativ relation (op.cit.: 35), det vil sige en enhed som omfatter et eller flere begreber. Adam identificerer denne enhed som en ytringsproposition (proposition énoncée) (ibid.). Samtidig afviser han muligheden af at tillægge den enkelte proposition typologisk status som henholdvis en narrativ, argumentativ eller deskriptiv proposition med den begrundelse, at typologisering af så lille en enhed som ytringen, er følsom overfor selv den mindste grammatiske ændring såsom indsættelse af et nægtelsesadverbium, tempusskift, spørgende pronomen etc. Han mener således ikke, at ytringerne i (1), (2) og (3) bør typologiseres som henholdvis en narrativ, en dialogal og en evaluerende/kommenterende proposition, omend de rent intuitivt kan fornemmes som således (op.cit.: 37):

(1) La marquise sortit à cinq heures

(2) Est-ce que la marquise sortit à cinq heures?

(3) La marquise n'est pas sortie à cinq heures

Denne følsomhed tydeliggøres, hvis man f.eks. ændrer (3) til:

(4) Ce jour-là, la marquise ne sortit pas à cinq heures

hvorved propositionen ændres fra at have evaluerende til at have narrativ status.

Dette får Adam til at fastholde, at typologiseringen i sekvenser nødvendigvis går ud over den enkelte proposition. Samtidig med at de grammatisk-syntaktiske markører er medkonstituerende for en propositions grundstruktur, er de ikke for Adam diskriminative for den typologiske kategorisering i sekvenser. Det er, efter hans mening, nødvendigt at inddrage relationer mellem større enheder og dermed samspillet mellem enkelte ytringers grammatiske karakteristika og den omkringliggende tekst, den såkaldte kotekst (op.cit.: 39). En proposition i form af en ytring er derfor at betragte i samspil med andre propositioner. Set ud fra et sekventielt synspunkt kan en proposition fungere enten som argument eller som konklusion og derved bidrage til at danne en argumentativ relation på det lokale mikroplan (ibid.). En kompleks sætning som:

(5) Les hommes aiment les femmes qui ont les mains douces

får først sin betydning via koteksten, hvor den kan fungere som præmisser i en argumentativ struktur inden for reklamegenren, eller som mo- 
rale i en fabel eller et eventyr. Det afhænger helt og aldeles, siger Adam, af dens plads set i et sekventielt perspektiv (op.cit.: 41).

Der er ingen tvivl om, at Adams teksttypologiseringsmodel er klogt og nøgternt udtænkt med en klar opdeling mellem en teksts kommunikative funktion og dens sproglige, strukturelle karakteristika. Det er en meget operationel model, når man søger overblik over en teksts makrostrukturelle komposition. Et eventyr vil således typisk indledes med en deskriptiv sekvens (Der var engang....), som igen vil udgøre en del af en større narrativ sekvens. Det samme gælder for mange andre tekstgenrer, en beretning, en indbydelse til reception, en kommentar etc., hvor den indledende teksttype bliver afløst af eller indgår i andre teksttyper i større tekstuelle konfigurationer. Men når dette er sagt, synes Adams model mindre operationel på relativt små tekstenheder. Dette problem vil jeg gøre nærmere rede for i det følgende.

\section{Typologisering af små tekstenheder}

De fleste reklameannoncer indeholder et kampagneslogan ${ }^{3}$, der fungerer som en selvstændig tekstuel enhed, der er propositionelt og grafisk adskilt fra brødteksten, eller ganske enkelt udgør reklamens eneste tekstuelle komponent. Da kampagnesloganet som regel kommer til udtryk i form af en enkelt ytring, er spørgsmålet, hvordan det kan typologiseres, og på hvilke præmisser typologiseringen kan foretages.

Efter de regler for typologisering, jeg har opstillet ovenfor, er det, som vi har set, mere eller mindre i modstrid med Adams sekvensmodel at typoligisere en enkelt ytring, det vil sige en enkelt proposition. For den argumentative teksttypes vedkommende, gælder det som sagt også, at den består af mindst to propositioner, som interagerer semantisk med hinanden: ingen konklusion uden præmisser og ingen præmisser uden konklusion. Det er grunden til, at Adam kategoriserer følgende eksempel som en prototypisk deskriptiv sekvens, men vel at mærke som en deskriptiv sekvens, der har et argumentativt formål. Det drejer sig om en undertekst til et fotografi af et bjergbestigningssted i en fransk egn:

Cadre verdoyant

rocher franc et massif

3 Kampagnesloganet skal forstås som det slogan, der benyttes i forbindelse med lanceringen af et specifikt produkt og må ikke forveksles med det firmaslogan, som producenten eller forhandleren benytter generelt $i$ alle kampagner. 
le Pas-de-l'ours

a tout pour plaire (op.cit.: 203).

Første linje består af en deskriptiv proposition, hvis tema er: ramme (cadre), hvortil der knytter sig en egenskab i form af et prædikat: grønklaedt (verdoyant). Anden linje består ligeledes af en deskriptiv proposition med temaet: klippe (rocher) og to tilhørende egenskaber: rank (franc) og massiv (massif). Læseren etablerer på basis af sit kendsskab til verden selv forbindelsen mellem ramme og klippe til det sted, som efterfølgende angives i linje tre. Stedet, Le pas-de-l'ours, danner helheden til de to tidligere angivne deltemaer: ramme og klippe. I fjerde linje tilføjes en ny egenskab: Le Pas-de-l'ours har alt hvad man kan $\phi n s k e$ sig (a tout pour plaire). På det illokutionære plan bevirker den positive egenskab, der signaleres via brugen af verbet plaire samt det manglende dativ objekt (vous plaire), at beskrivelsen kommer til at fungere som et påskud for en anbefaling af stedet le Pas-de-l'ours.

Som det fremgår af kategoriseringen af dette eksempel, skelner Adam meget konsekvent mellem på den ene side en teksts sekventielle struktur og dens illokutionære værdi. Man kan imidlertid stille spørgsmålstegn ved, om ikke denne funktionelle dimension allerede er indlejret i den sekventielle struktur i eksemplet ovenfor. Jeg vil i det følgende plædere for, at eksemplet kan interpreteres ikke som en deskriptiv, men som en argumentativ sekvens. Til støtte for min påstand vil jeg opstille to analyser, som begge kategoriserer eksemplet som en argumentativ sekvens. Den første analyse bryder med Adams principper for den syntagmatiske afgrænsing af propositionen som følge af, at han tilsyneladende kobler denne til helsætningen. Den anden analyse griber ind i hans paradigmatiske kategorisering inden for den enkelte makroproposition.

Lad os indledningsvis opløse Adams propositionelle basisenhed i form af en helsætning, og i stedet afgrænse propositionen som en fonetisk enhed, der har et selvstændigt betydningsindhold. I så fald vil det propositionelle indhold i den første del af sekvensen: Cadre verdoyant, rocher franc et massif kunne interpreteres som en makroproposition med legitimerende værdi i forhold til det propositionelle indhold i den anden makroproposition: le Pas de l'ours a tout pour plaire, altså med andre ord som to makropropositioner, hvor imellem der er en argumentativ relation. For at underbygge denne analyse kan man teste den semantiske relation ved f.eks. at indsætte en kausal markør mellem de to 
propositioner. Eksemplet indledes med et frit prædikat, hvor forbindelsen til subjektet i mange tilfælde er af mere eller mindre kausal karakter (Ellerup Nielsen 1996: 337). Desuden bygger den argumentative struktur altid på en kausal relation på det dybdelogiske niveau (Plantin 1996: 40). Hvis vi derfor indsætter grâce à i eksemplet ovenfor, foregribes den positive værdi, som sproghandlingen anbefaling er et udtryk for, og som er artikuleret via ordet plaire:

Grâce à son cadre verdoyant

(med/på grund af sine grønklædte omgivelser)

et son rocher franc et massif

(og sine ranke og massive klipper)

le Pas de l'Ours a tout pour plaire

(har Pas de l'Ours alt hvad man kan ønske sig).

I skematisk form får vi følgelig:

$\begin{array}{ll}- & \begin{array}{l}\text { Le Pas de l'Ours har } \\ \text { grønklædte omgivelser .. } \\ \text { og ranke og solide klipper }\end{array} \\ \text { P.arg. 0 } & \text { P. arg. 1 }\end{array}$

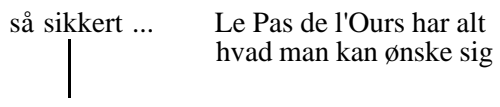

$\begin{array}{ll}\text { P. } \arg .2 & \text { P. arg. } 3\end{array}$

med mindre...

P. arg. 4

Denne argumentative interpretationsmulighed for sekvensen ovenfor kan forklares ved, at den propositionelle basisenhed ikke, efter min mening, bør knyttes til helsætningen, men til en enhed, der har en umiddelbar selvstændig betydning, således som f.eks. det frie prædikat, hvor den semantiske tilknytning til resten af sætningen netop er forholdvis løs. Den eneste urokkelige betingelse som skal være opfyldt er naturligvis, at der skal mindst to potentielle makropropositioner til for at kunne udløse den argumentative struktur.

Den anden analyse som også understøtter den argumentative interpretation af eksemplet, bryder med et af de paradigmatiske kriterier for kategoriseringen i teksttyper. På trods af at Adam, som vi har set, afviser, at en enkelt ytring kan artikulere en bestemt teksttype, mener jeg, at det er relevant at skelne mellem påstande af typen: Der står en mand ovre på den anden side af gaden og Peters stil er den bedste. Hvor den første påstand isoleret set har en referentiel værdi, som uden videre kan 
underkastes en sandhedstest, har den sidste påstand evaluerende værdi. Da evaluering er knyttet til manifestationen af afsenders subjektivitet på udsigelsesniveauet, kan tilstedeværelsen af dette element undersøges nærmere ved, at man underkaster eksemplerne en sproglig test. Lad os derfor se på, hvad der sker, hvis man indleder eksemplerne med et subjektivt ladet adverbial som f.eks. efter min mening:

*(6) Efter min mening står der en mand ovre på den anden side af gaden

(7) Efter min mening er Peters stil den bedste

Evaluerende påstande kan i modsætning til referentielle påstande følge umiddelbart efter et subjektivt meningsytringselement, således som det fremgår af testen i (6) og (7). Evaluerende påstande har indbyggede argumentative spor, fordi de kalder på legitimering i udsigelsessituationen, hvorimod referentielle påstande kan stå alene i den forstand, at de er umiddelbart verificerbare, og dermed ukontroversielle for udsigeren. Hvis man overfører dette perspektiv til reklamer, hvor lovprisningen af produkt eller producent, som allerede antydet, er reglen snarere end undtagelsen, finder man naturligt nok en høj frekvens af evaluerende påstande i denne genre. Jeg mener således yderligere at kunne begrunde analysen af eksemplet ovenfor som en argumentativ mikrosekvens med, at det netop indeholder en evaluerende påstand: Le Pas-de-l'ours a tout pour plaire. Denne analyse kræver imidlertid yderligere forklaringer.

For at underbygge min analyse vil jeg ty til Tuija Virtanens distinktion mellem teksttype (text type) forstået som en tekststrategi (og altså mere eller mindre identisk med Adams teksttypebegreb) og diskurstype (dicourse type), som befinder sig på et mere overordnet tekstuelt niveau og benyttes om den funktion, en tekst opfylder (Virtanen 1992: 298). Virtanens kategorisering går blandt andet ud på at vise, hvilke teksttyper der kan realisere hvilke diskurtyper. Hendes pointe er blandt andet, at den argumentative diskurstype kan realiseres via samtlige teksttyper: den narrative, den deskriptive, den eksplikative m.m. Adams analyse af eksemplet fra før er således et udmærket eksempel på, at den deskriptive teksttype, som kommer til syne i den sproglige overflade, tjener til opfyldelse af en argumentativ funktion på det illokutionære niveau. Omvendt kan den argumentative teksttype altid kun, ifølge Virtanen, realisere den argumentative diskurstype (op.cit.: 303). Det vil altså sige, at har man først set spor af argumentation i form af bestemte markører 
såsom argumentative konnektorer, adverbier, eller som her, værdiladede ord på det i Adams forstand teksttypologiske niveau, så kan teksten kun tjene et argumentativt formål. Eftersom argumentation går ud på at få modtager til at akceptere en tese ved at understøtte en påstand med en anden påstand, og evaluering er et udtryk for afsenders subjektive holdning til en tese i en bestemt udsigelsessituation, kan man mellem evaluerende elementer og argumentation etablere en direkte forbindelse. Men for referentielle påstande gælder det, at da de hverken er forbundet med subjektive eller argumentative elementer, er der tilsyneladende bestemte restriktioner på, hvilke funktionelle relationer, de kan etablere til den efterfølgende diskurs. Dette er ikke mindst interessant i forbindelse med reklametekster, som ofte lægger op til, at læseren netop selv skal videreræsonnere: Er du udkфrt kl. 3? (Så snup en kop Medova). Sproglige tests, hvor evaluerende og referentielle påstande sættes ind i en større diskursiv sammenhæng tjener til at understøtte min antagelse af, at den pragmatiske dimension i et vist omfang har indflydelse på en teksts strukturelle, og dermed sekventielle egenskaber.

For at afgøre om en ytring artikulerer en argumentativ eller en deskriptiv teksttype kan man ved hjælp af en spørgsmål-svar test undersøge de mulige relationer til en potentielt efterfølgende ytring. Lad os mellem parvise ytringer, hvor den første består af henholdvis en evaluerende og en referentiel påstand, benytte konstruktioner med hvorfor/ fordi. Hvis der mellem de to ytringer således kan etableres en kausal forbindelse, vil jeg hævde, at den deskriptive teksttype er udelukket. De to eksempler fra før på henholdvis en referentiel og en evaluerende påstand bliver da som følger:

(8) Der står en mand ovre på den anden side af gaden. Han ser skummel ud

*(8') Hvorfor står der en mand ovre på den anden side? Fordi han ser skummel ud

(9) Peters stil er den bedste. Den er velskrevet.

(9') Hvorfor er Peters stil den bedste? Fordi den er velskrevet

Som det fremgår af eksemplerne er det ikke umiddelbart muligt at etablere en kausal forbindelse til den referentielle påstand i (8). Men som man ser i (9') kan den evaluerende påstand til gengæld udmærket indgå i en kausal forbindelse. Hermed vil jeg altså plædere for, at evaluerende påstande, som er ret udprægede i reklametekster, bør interpreteres som 
makropropositioner i argumentative sekvenser og ikke som propositioner i deskriptive sekvenser.

Da jeg har anvendt et yderst sparsomt eksempelmateriale til støtte for min alternative kategorisering af Adams eksempel ovenfor, vil jeg for fuldstændighedens skyld runde af med et par aktuelle reklametekster fra danske dag- og ugeblade, som synes at artikulere den argumentative teksttype på de nye præmisser for kategorisering, jeg har indført ovenfor:

(10) Estrella Pom's

svær at holde fritterne fra!

Nye, sprøde kartoffelsnacks med stærkt fristende barbecuesmag.

(11) Petit Point. Klasse over bordet

Petit Point - et formfuldendt og funktionelt bestik

fremstillet i kvalitetsstål

Kunstneren Bertil Vallien har designet

Petit Point for Gense og for Dem

Priseksempel: Kniv, gaffel eller ske, pr. stk. kr. 158.

Gense stålbestik - ouvertruffen i stil og elegance

(12) Samtale fremmer forståelsen.

Mobilix er Danmarks nye teleselskab.

Om kort tid introducerer vi et helt nyt mobilsystem.

Vores teknologi er sandsynligvis verdens mest avancerede.

Men det er jo kun interessant, hvis vi kan gøre det nemmere at tale sammen. Så det gør vi.

Mobilix den nye talemåde

Hvis vi ser nærmere på relationen mellem det fremhævede kampagneslogan i hvert af eksemplerne 10-12, kan vi i alle tre tilfælde indlede med et spørgende pronomen:

(10') Hvorfor er Estrella Pom's svær at holde fritterne fra?

(11') Hvorfor er Petit Point klasse over bordet?

(12') Hvorfor fremmer samtale forståelsen?

Til de første to spørgsmål kan vi yderligere udpege en proposition, som synes at besvare det stillede spørgsmål fra den efterfølgende brødtekst: Fordi det er nye sprøde kartoffelsnacks... (10), Fordi det er et formfuldt og funktionelt bestik... (11). Men svaret behøver ikke nødvendigvis at 
figurere eksplicit i brødteksten, sådan som det fremgår af det sidste eksempel. Her er spørgsmål-svar relationen mere subtil, idet det indledende slogan kan fungere som svaret på et spørgsmål, som indirekte stilles længere fremme i brødteksten:

(13) Hvorfor gør vi det nemmere at tale sammen? Fordi samtale fremmer forståelsen.

Endelig kan man fremhæve typen af reklametekster, i hvilke svaret ikke figurerer eksplicit i den sproglige overflade, men hvor legitimeringen præsenteres, som om den giver sig selv, eller som tidligere antydet, den projiceres over på det implicitte plan og etableres her via inferens af læseren selv:

(14) Indretning er mere fantasi end penge...

Ikea giver bedre råd

(Inferens: Ikea sætter fantasien igang, uden at det koster noget)

\section{Konklusion}

Adams teksttypologiseringsmodel udgør et godt og brugbart instrument i både det praktisk-pædagogiske såvel som det abstrakt-teoretiske arbejde med tekster og tekstkategorisering.

Modellens fokus på samspillet mellem små og større konfigurationelle enheder i en tekst understreger den dynamik, som tekster i almindelighed udviser. Dog håber jeg at have påvist, at en vis justering af modellen er påkrævet, hvis man ønsker at typologisere selvstændige mikropropositionelle enheder, hvormed reklameannoncen som følge af sin kortform er særligt velforsynet. Det gælder dels den formelle afgrænsning af makropropositionen, dels den teksttypologiske artikulation inden for rammerne af den enkelte makroproposition.

Som det fremgår af de eksempler og tests, jeg har gennemløbet, er der noget, der tyder på, at Adams teksttypologiseringsmodel er for grovmasket. Dette giver sig blandt andet udslag i, at den ikke indfanger de strukturelle forskelle, som evaluerende og referentielle påstande synes at udvise på det diskursive plan. Reklamegenren er, på trods af sin tendens til at kamouflere sin argumentative funktion bag den uskyldige beskrivelse, ikke desto mindre spækket med subjektive og dermed evaluerende elementer, som kommer til syne i analyser af det mikropropositionelle niveau. Genrens konstante spil på beskrivelse og 
argumentation gør den derfor særligt velegnet til at illustrere, hvorledes pragmatisk-funktionelle elementer afspejler sig i en teksts sekventielle struktur.

\section{Referencer}

Adam, Jean-Michel (1985a): Le texte narratif. Paris: Nathan-Université.

Adam, Jean-Michel (1985b): Quels types de texte? In Le Français dans le monde 192. Paris: Hachette.

Adam, Jean-Michel (1987): Types de séquences textuelles élémentaires. In Pratiques 56. Metz.

Adam, Jean-Michel (1990): Eléments de linguistique textuelle. Liège: Mardaga.

Adam, Jean-Michel (1992): Les textes : types et prototypes. Paris: Nathan-Université.

Adam, Jean-Michel (1996): L'argumentation dans le dialogue. In Langue Française 112. 31-48.

Adam, Jean-Michel \& Petitjean, A (1989): Le texte déscriptif. Paris: Nathan-Université.

Adam, Jean-Michel \& Bonhomme, Marc (1997): L'argumentation publicitaire. Paris: Nathan-Université.

Frandsen, Finn \& Pilegård, Morten (1997): Text Type. In Verschueren, Östman, Blommaert \& Bulcaen (eds.): Handbook of Pragmatics. Amsterdam: John Benjamins Publ. Co.

Nielsen, Anne Ellerup (1996): Argumentationsstrategier i franske prasentationsbrochurer - Fra det sproglige til det retoriske niveau, Ph.d.-afhandling, HHA.

Nielsen, Anne Ellerup \& Nølke, Henning (1991): Persuasion Disguised as Description - An Example of Argumentation in the Company Brochure. In I. Z. Zagar (ed.): Speech Acts: Fiction or Reality? Ljubliana.

Toulmin, Stephen (1996): The Uses of Argument. Cambridge: University Press [1. udg. 1959].

Virtanen, Tuija (1992): Issues of Text Typology: Narrative - a 'Basic' Type of Text? In Text 12 (2). 293-310.

Werlich, Egon (1979): Typologie der texte. Heidelberg: Quelle \& Meyer [2. udg.]. 
